\title{
Genetic Linkage of Recessive Dystrophic Epidermolysis Bullosa to the Type VII Collagen Gene
}

\author{
Alain Hovnanian, * Philippe Duquesnoy, * Claudine Blanchet-Bardon, ${ }^{*}$ Robert G. Knowlton, ${ }^{5}$ Serge Amselem, * \\ Mark Lathrop," Louis Dubertret, ${ }^{*}$ Jouni Uitto, ${ }^{3}$ and Michel Goossens ${ }^{*}$ \\ *Laboratoire de Génétique moléculaire, Institut National de la Santé et de Recherche Médicale (INSERM) Unité 91, Hôpital Henri \\ Mondor, 94010 Créteil, France, ${ }^{\ddagger}$ Service de Dermatologie, Hopital Saint-Louis, 75010 Paris, France; ${ }^{\S}$ Departments of Dermatology, and \\ Biochemistry and Molecular Biology, Jefferson Medical College, and Section of Molecular Dermatology, Jefferson Institute of Molecular \\ Medicine, Thomas Jefferson University, Philadelphia, Pennsylvania 19107; and "Centre d'Etude du Polymorphisme Humain, \\ INSERM Unité 358, 75010 Paris, France
}

\begin{abstract}
Generalized mutilating recessive dystrophic epidermolysis bullosa (RDEB) is characterized by extreme skin fragility owing to loss of dermal-epidermal adherence. Immunohistochemical studies have implicated type VII collagen, the major component of anchoring fibrils, in the etiology of RDEB. In this study, we demonstrate genetic linkage of the type VII collagen gene and the generalized mutilating RDEB phenotype. We first identified a Pvull polymorphic site by digestion of an amplified product of the type VII collagen gene, which was shown to reside within the coding region. Genetic linkage analysis between this marker and the RDEB phenotype in 19 affected families which were informative for this polymorphism showed no recombination events, and gave a maximum lod score of 3.97 at a recombination fraction $(\theta)$ of 0 , demonstrating that this DNA region is involved in this form of RDEB. These data provide strong evidence that the type VII collagen gene, which has also been linked with the dominant form of the disease, harbors the mutation(s) causing the generalized mutilating form of RDEB in these families, thus underscoring the major functional importance of type VII collagen in basement membrane zone stability. (J. Clin. Invest. 1992. 90:1032-1036.) Key words: anchoring fibrils • dermal-epidermal junction • polymerase chain reaction • restriction fragment length polymorphism • lod score.
\end{abstract}

\section{Introduction}

Epidermolysis bullosa (EB) ${ }^{1}$ is a group of inherited diseases characterized by blistering of the skin and mucous membranes, with an incidence of $\sim 1$ in 50,000 (1). The clinical phenotype of EB varies from a relatively mild blistering tendency to severe mutilating and scarring forms. This group of diseases is also genetically heterogeneous, and both dominant and recessive

Address reprint requests to Dr. Hovnanian, Laboratoire de Génétique Moléculaire, INSERM U.91, Hopital Henri Mondor, 51, avenue de Maréchal de Lattre de Tassigny, 94010 Créteil, France.

Received for publication 30 January 1992 and in revised form 29 April 1992.

1. Abbreviations used in this paper: EB, epidermolysis bullosa; similarly DDEB and RDEB, dominant dystrophic and recessive dystrophic EB; PCR, polymerase chain reaction; RFLP, restriction fragment length polymorphism.

J. Clin. Invest.

(c) The American Society for Clinical Investigation, Inc. 0021-9738/92/09/1032/05 \$2.00

Volume 90, September 1992, 1032-1036 inheritance occur. EB can be divided into three major types on the basis of the level of tissue separation and blister formation within the skin (2): (a) simplex, nonscarring forms, with cleavage at the level of basal keratinocytes, which have recently been shown to be due to mutations in keratin 14 and $5(3-5) ;(b)$ junctional forms, with tissue separation within the dermal-epidermal basement membrane at the level of the lamina lucida; (c) dystrophic (scarring) forms, with tissue separation within the upper papillary dermis at the level of the anchoring fibrils. Several clinically distinct subgroups have been described in each of these major categories (6).

Dystrophic EB occurs in two forms: recessive dystrophic $\mathrm{EB}$ (RDEB) and dominant dystrophic EB (DDEB). The generalized mutilating form of RDEB (Mendelian Inheritance in Man Access No. 226600, i.e., the Hallopeau-Siemens type) is the most severe variant of dystrophic EB, characterized by extensive blistering of the skin and mucous membranes, resulting in mutilating scarring which leads to pseudosyndactyly, esophageal strictures, dystrophy or absence of nails, flexural contractures, and can lead to death from malnutrition, septicemia, or metastatic squamous cell carcinoma $(1,2)$. The other subtypes of RDEB (generalized nonmutilating, localized, and inverse forms), as well as the dominant forms of dystrophic EB are characterized by less severe blistering and scarring, and the fusion of digits, characteristic of the mutilating recessive form, is absent.

Type VII collagen, the major component of anchoring fibrils that form attachment complexes between the epidermis and the dermis $(7,8)$, has recently been implicated in the pathogenesis of both dominant and recessive forms of dystrophic EB. This conclusion was based on previous reports of altered ultrastructural appearance and paucity of anchoring fibrils in both forms of the disease (9-12). Furthermore, immunocytochemistry and immunoelectron microscopy studies using polyclonal and monoclonal antibodies against type VII collagen epitopes have revealed an absence or a diminution of type VII collagen in the skin of patients with the recessive form (13-18), although immunostaining in the dominant forms is normal. In addition, intracellular retention of type VII collagen epitopes in basal and suprabasal keratinocytes has been described in two patients with DDEB (19) and in a patient with generalized RDEB (20). These observations suggest that type VII collagen could be the defective gene in both dominantly and recessively inherited dystrophic EB.

Recent molecular genetic analyses of three families with the dominant dystrophic type of EB have shown close linkage to the type VII collagen gene (COL7A1) $(21,22)$, which has been mapped to chromosomal region $3 \mathrm{p} 21.1$ (23). These analyses were made possible by the development of human type VII 
collagen cDNAs (23) and subsequent identification of a Pvull restriction fragment length polymorphism (RFLP) in COL7A1 by means of Southern blot analyses using the human type VII collagen cDNA clone K-131 (21). In this study, we have tested the hypothesis that generalized mutilating RDEB (the Hallopeau-Siemens type) is linked to the type VII collagen locus. Our results for 19 informative families demonstrate close genetic linkage between the COL7A1 locus and the RDEB phenotype.

\section{Methods}

\section{Families}

We studied 24 affected families with the severe generalized mutilating form of RDEB (the Hallopeau-Siemens variant). Five families (FIFV) had two or more living affected offspring, and consanguinity was found in families FI, FIV, and FXIV (Table I). The diagnosis was based on family history, clinical examination, and electron microscopic evaluation. All the patients had severely scarring blistering since birth, resulting in erythematous and atrophic skin with milia, affecting all skin surfaces, with pseudosyndactyly characteristic of the mutilating recessive form of dystrophic EB (Fig. 1), flexural contractures, nail loss, and frequent esophageal strictures. Skin biopsy specimeṇs for electron microscopy analysis were obtained after mild rubbing of nonblistered skin of the groin, and the samples were processed using standard methods (24). Ultrastructural studies revealed absent (Fig. 2, bottom) or markedly reduced and rudimentary anchoring fibrils as compared to the control (Fig. 2, top), and tissue cleavage beneath the lamina densa, whereas the lamina lucida, hemidesmosomes, and the interstitial collagen fibers within the dermis were normal.

\section{DNA analysis}

Amplification of genomic DNA by means of the polymerase chain reaction (PCR). Genomic DNA was isolated from peripheral blood leukocytes and amplified as previously described (25). Two sets of primers flanking each of the Pvull sites identified in the 1.9-kb human type VII collagen cDNA clone $\mathrm{K}-131$ were designated as primers 1 ( 5 '-CCATGAGGCACCAGATACTC-3'; nucleotides 5-24) and 2 (5'-GTCCACC-

Table I. Characteristics of the RDEB Families Studied, Informative for the Type VII Collagen PvuII RFLP

\begin{tabular}{rcc}
\hline Family & Consanguinity & $\begin{array}{c}\text { Number of offspring with } \\
\text { RDEB/number of offspring }\end{array}$ \\
\hline I & 1st degree & $3 / 4$ \\
II & no & $2 / 3$ \\
III & no & $2 / 2$ \\
IV & 2nd degree & $2 / 2$ \\
V & no & $2 / 2$ \\
VI & no & $1 / 5$ \\
VII & no & $1 / 5$ \\
VIII & no & $1 / 4$ \\
IX & no & $1 / 3$ \\
X & no & $1 / 3$ \\
XI & no & $1 / 3$ \\
XII & no & $1 / 3$ \\
XIII & no & $1 / 3$ \\
XIV & 1st degree & $1 / 3$ \\
XV & no & $1 / 2$ \\
XVI & no & $1 / 2$ \\
XVII & no & $1 / 2$ \\
XVIII & no & $1 / 2$ \\
XIX & no & $1 / 2$ \\
\hline
\end{tabular}

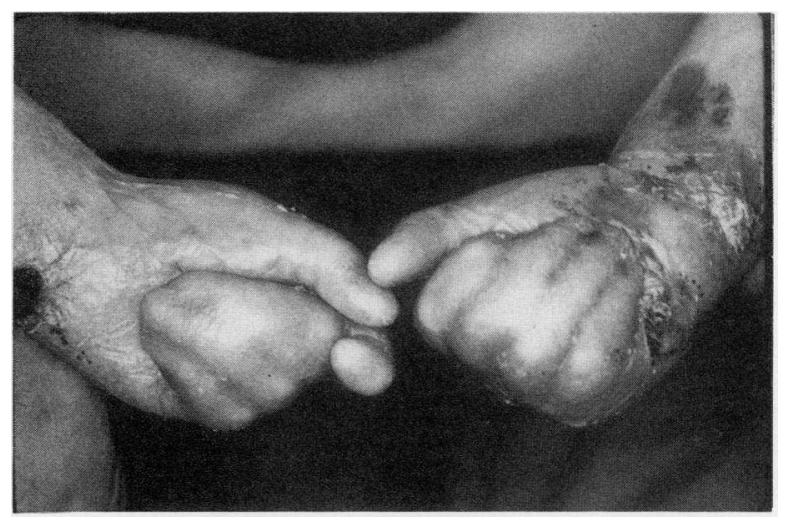

Figure 1. Clinical features of a patient with severe generalized mutilating RDEB presenting pseudosyndactyly of fingers, atrophic skin, and nail loss.

ACACGTAGTTCAAT-3'; nucleotides 1261-1241), and 3 (5'-CTCCCCACTGTTCCCACTGA-3'; nucleotides 2115-2134) and 4( $5^{\prime}$-TGAGTAGTGAAGGATGCCTG-3'; nucleotides 2701-2682). A third set of primers, designated as primers 5 ( 5 '-GAGAGGACAAGTTGGGCCTCC-3'; nucleotides 3046-3066) and 6 (5'-GTCACCCTTCATGGCTGTTC-3'; nucleotides 4469-4450) was used to amplify the intronic Pvull site located within the genomic region corresponding to the K-131 cDNA clone (unpublished data). The numbers refer to the nucleotide position within the genomic region corresponding to this
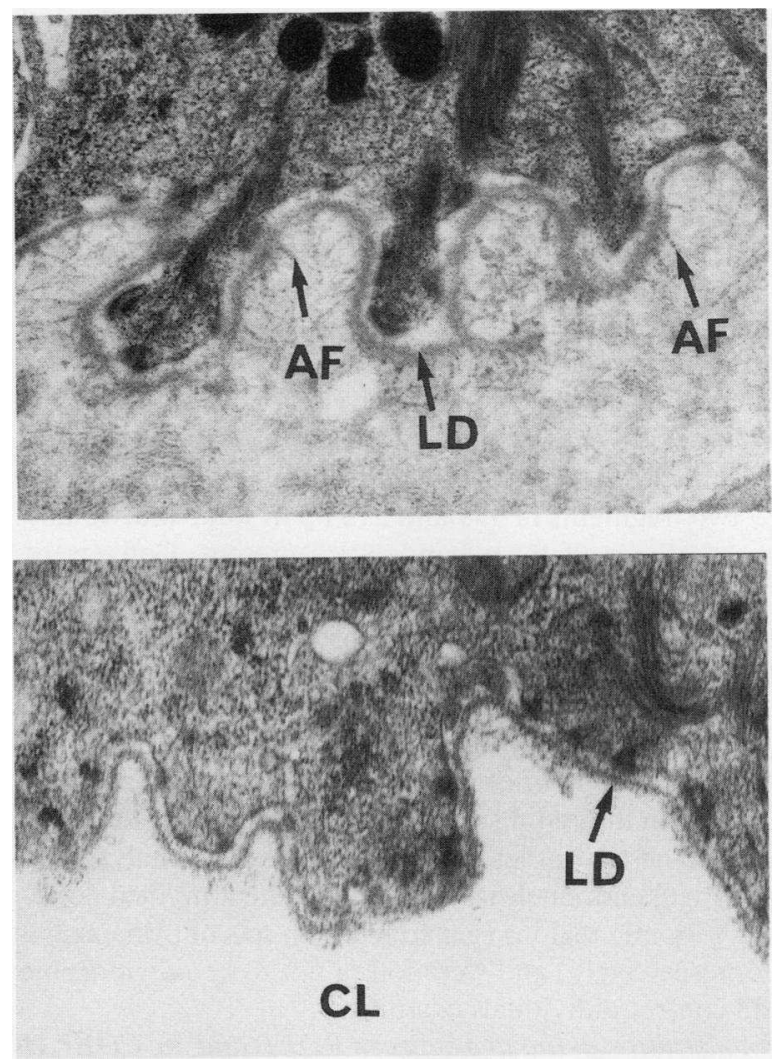

Figure 2. Top: Electron micrograph of the dermal-epidermal junction of normal human skin. Anchoring fibrils $(A F)$ are seen beneath the lamina densa $(L D)$. Original magnification 10,000. Bottom: Electron micrograph of the skin biopsy of a patient with generalized mutilating RDEB, showing cleavage $(C L)$ below the lamina densa $(L D)$ and absence of recognizable anchoring fibrils. Original magnification 10,000 . 
$\mathrm{K}-131$ cDNA clone. The numbers refer to the nucleotide position within the genomic region corresponding to this $\mathrm{K}-131$ clone. 30 cycles were performed, each consisting of denaturing at $94^{\circ} \mathrm{C}$ for $1 \mathrm{~min}$, annealing at $55^{\circ} \mathrm{C}$ for $1 \mathrm{~min}$, and extension at $72^{\circ} \mathrm{C}$ for $1.5 \mathrm{~min}$.

Analysis of the PCR products. One-tenth of the PCR reaction product was digested for $3 \mathrm{~h}$ with Pvull restriction enzyme ( $10 \mathrm{U} / 10 \mu \mathrm{l}$ of PCR product) (New England Biolabs, Beverly, MA), separated by electrophoresis on a $6 \%$ polyacrylamide gel, stained with ethidium bromide, and photographed. Single-strand DNA was generated by PCR using unequal amounts of primers 1 and $2(1 \mathrm{pmol} / 50 \mathrm{pmol})$, as previously described (26). The PCR product was then purified on microconcentrators (Centricon 100, Amicon Corp., Danvers, MA) and sequenced using internal primers by means of the dideoxynucleotide termination method (27) (Sequenase, U.S. Biochemical Corp., Cleveland, $\mathrm{OH}$ ).

Linkage analysis. Linkage analysis was carried out with the LINKAGE program (28). Lod score ${ }^{2}$ calculations took into account consanguinity in families FI, FXIV (1st degree), and FIV (2nd degree). The allelic frequency of the type VII collagen Pvull RFLP was calculated to be 0.29 in the RDEB families studied.

\section{Results}

Localization of the Pvull RFLP within the COL7A1 coding region. As indicated above, we have recently identified an informative Pvull polymorphism within the COL7A1 by means of Southern-blot analyses. This Pvull RFLP showed the presence of 3.6-kb/ 1.9- and 1.7-kb alleles, with an estimated allelic frequency in a general Caucasian population of $0.65 / 0.35$ and a polymorphism information content of 0.35 (21). To develop a rapid PCR-based method for the detection of this RFLP, we surveyed the genomic region corresponding to the K-131 type VII collagen cDNA for the presence of Pvull sites. Examination of the nucleotide sequences within the 1.9-kb K131 cDNA identified two Pvull restriction sites at nucleotides positions ${ }^{3}$ 374 and 1153 (numbering as in reference 23), and sequencing of the introns of the corresponding gene segment identified an additional Pvull site in a normal control individual. Amplification with primers 1 and 2 of the genomic region spanning the Pvull site at nucleotide position 374 yielded a 1,257-bp PCR product in 38 normal individuals. Subsequent digestion by Pvull endonuclease resulted in the replacement of the 1,257-bp band by two fragments of 939 and 318 bp in some individuals, whereas in others all three bands were present. Conversely, digestion of this PCR product with Pvull did not change the migration position in other individuals. Direct sequencing of the corresponding DNA segment revealed an A-G substitution in the third position ( nucleotide 375 ) of a proline codon (Fig. 3), which abolished the corresponding Pvull site, but did not change the encoded amino acid, indicating that this nucleotide variation within the coding region of the gene was a silent polymorphism. The two other Pvull sites were also analyzed by means of Pvull endonuclease digestion of the amplified corresponding genomic regions (generated with sets of primers 3-4 and 5-6, respectively) and were found not to be polymorphic in the 38 control individuals examined.

Demonstration of linkage between RDEB and the COL7AI locus. We used this Pvull RFLP to test the hypothesis of genetic linkage between the COL7A1 gene and generalized mutilating

2. A lod score is defined as the logarithm, to the base 10 , of the ratio of the odds in favor of linkage to the odds against linkage.

3. The nucleotide position refers to the $5^{\prime}$ base of the Pvull recognition sequence.

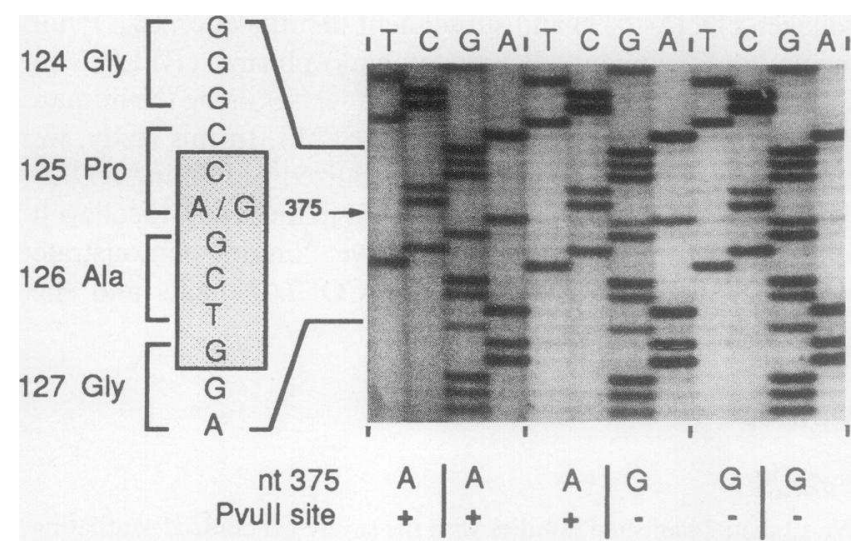

Figure 3. Characterization of the polymorphic Pvull site within the coding sequence of the type VII collagen gene by direct sequence analysis. The sequences shown are those of the positive strand. Allelic variants of the type VII collagen gene arise from an A-G substitution at the third base of a proline codon at position 125 which does not change the amino acid, but abolishes the corresponding Pvull site ( $5^{\prime}$ CAGCTG $3^{\prime}$ ). The numbers $124-127$ refer to the position of the corresponding amino acids in the K131 cDNA clone. + and - respectively indicate the presence and absence of the Pvull RFLP on each allele.

RDEB. We studied 24 affected families with clinical features characteristic of generalized mutilating RDEB (Hallopeau-Siemens type). Genomic DNA amplification with primers 1 and 2 and subsequent digestion by Pvull endonuclease were performed in all members of the families. The corresponding allelic frequencies in these families were $70.9 \%$ for the $1,257-b p$ allele, and $29.1 \%$ for the $939-b p / 318-b p$ alleles. Nineteen of these families were informative for the Pvull RFLP (Table I). Linkage analysis between type VII collagen alleles and the RDEB phenotype showed no obligate recombination events. The RDEB phenotype segregated with either the Pvull polymorphic site, or with the type VII collagen allele which did not have the Pvull site, or with both alleles, indicating no linkage disequilibrium.

The lod scores at $\theta=0.0$ for each family were calculated using the LINKAGE program (28). As shown in Table II, the individual lod scores in these families varied from -0.35 to 0.73 at $\theta=0.0$, and the combined lod score for the 19 informative families was 3.97 at $\theta=0.0$, thus establishing linkage.

\section{Discussion}

We used the Pvull RFLP to test the hypothesis of genetic linkage between the COL7A1 gene and generalized mutilating RDEB. As described in Table II, we obtained a maximum lod score of 3.97 at $\theta=0.0(0.0-0.11$ for the 1-lod unit confidence interval) in the 19 families. A lod score $>3$ is usually considered as sufficient statistical evidence to establish linkage between a random marker and a disease locus, and an even less stringent criterion is frequently applied for a candidate gene (29), such as type VII collagen in the dystrophic forms of EB. In addition, due to the fact that the polymorphic site used in this study was intragenic, the chance of recombination between this Pvull site and the type VII collagen gene was very unlikely. Our data therefore establish that the defect responsible for RDEB in the families studied here lies within or near the type VII collagen gene. 
Table II. Lod Scores between RDEB Phenotype and Type VII Collagen in the Families Studied

\begin{tabular}{lrrrrrrr}
\hline & \multicolumn{7}{c}{ Recombination fraction $(\theta)$} \\
\cline { 2 - 8 } Family & \multicolumn{1}{c}{0.0} & \multicolumn{1}{c}{0.01} & \multicolumn{1}{c}{0.05} & \multicolumn{1}{c}{0.1} & \multicolumn{1}{c}{0.2} & \multicolumn{1}{c}{0.3} & \multicolumn{1}{c}{0.4} \\
\hline I & 0.59 & 0.58 & 0.53 & 0.46 & 0.32 & 0.18 & 0.07 \\
II & 0.12 & 0.12 & 0.10 & 0.08 & 0.05 & 0.02 & 0.01 \\
III & 0.30 & 0.29 & 0.26 & 0.21 & 0.13 & 0.06 & 0.02 \\
IV & 0.65 & 0.63 & 0.55 & 0.45 & 0.27 & 0.13 & 0.03 \\
V & 0.30 & 0.28 & 0.22 & 0.15 & 0.05 & 0.01 & 0.00 \\
VI & 0.62 & 0.61 & 0.55 & 0.47 & 0.31 & 0.16 & 0.05 \\
VII & 0.20 & 0.19 & 0.17 & 0.14 & 0.09 & 0.04 & 0.01 \\
VIII & -0.23 & -0.22 & -0.18 & -0.14 & -0.07 & -0.03 & -0.01 \\
IX & 0.25 & 0.24 & 0.21 & 0.18 & 0.11 & 0.05 & 0.01 \\
X & -0.35 & -0.33 & -0.26 & -0.19 & -0.10 & -0.04 & -0.01 \\
XI & -0.35 & -0.33 & -0.26 & -0.19 & -0.10 & -0.04 & -0.01 \\
XII & 0.25 & 0.24 & 0.21 & 0.18 & 0.11 & 0.05 & 0.01 \\
XIII & 0.25 & 0.24 & 0.21 & 0.18 & 0.11 & 0.05 & 0.01 \\
XIV & 0.73 & 0.71 & 0.63 & 0.53 & 0.35 & 0.19 & 0.06 \\
XV & 0.12 & 0.12 & 0.09 & 0.06 & 0.02 & 0.00 & 0.00 \\
XVI & 0.12 & 0.12 & 0.09 & 0.06 & 0.02 & 0.00 & 0.00 \\
XVII & 0.12 & 0.12 & 0.10 & 0.08 & 0.05 & 0.02 & 0.01 \\
XVIII & 0.12 & 0.12 & 0.10 & 0.08 & 0.05 & 0.02 & 0.01 \\
XIX & 0.12 & 0.12 & 0.10 & 0.08 & 0.05 & 0.02 & 0.01 \\
Total & 3.97 & 3.87 & 3.43 & 2.87 & 1.81 & 0.92 & 0.28 \\
& & & & & & & \\
\hline & & & & & & &
\end{tabular}

Lod score calculations were carried out with the LINKAGE program (28). The allelic frequency of the type VII collagen PvuII RFLP was calculated to be 0.29 from our family data.

Although linkage between the type VII collagen gene and the RDEB locus does not demonstrate a causal relationship between this candidate gene and the disease phenotype, we observed no obligate recombinants with the type VII collagen gene (three families with slightly negative lod scores all included one parent who was uninformative for linkage to the marker locus). The lack of obligate recombination, together with compelling evidence for abnormal expression of type VII collagen in skin from RDEB patients (13-18), strongly suggest that type VII collagen is the gene harboring the deleterious mutation in our RDEB families.

Electron microscopic studies have consistently found either an absence of anchoring fibrils in the skin of patients with generalized RDEB, or a reduction in number and rudimentary appearance of anchoring fibrils (9-12). Immunolabelling studies using polyclonal $(15,16)$ and monoclonal antibodies against type VII collagen epitopes $(13,14,17)$ have revealed absent (13-16), or weak and discontinuous staining (17) along the dermal-epidermal basement membrane zone in skin from these patients. In addition, intracellular retention of type VII collagen epitopes in basal and suprabasal keratinocytes has been described in a patient with generalized RDEB (20).

On the basis of these findings, it has been assumed that the absence or abnormalities of anchoring fibrils in this form of EB were due to either impaired anchoring fibril formation caused by a defect in type VII collagen synthesis or processing, or destruction of normal anchoring fibrils by proteases such as collagenase. In some patients, collagenolysis in the upper papillary dermis has been reported, together with enhanced collage- nase $(30,31)$ or stromelysin (32) activity, raising the possibility of excessive degradation of type VII collagen as a cause of diminished or absent anchoring fibrils. However, two groups working independently including our own $(33,34)$ have recently excluded genetic linkage between the collagenase and stromelysin genes and the severe generalized RDEB phenotype in two unrelated families.

In the present study, all the patients conformed to the clinical features of severe generalized mutilating RDEB (Hallopeau-Siemens variant) (2). The absence of recombination events between the type VII collagen gene and the RDEB locus in the 19 families studied suggests that the genetic defect in this group of patients lies in the same locus, i.e., the type VII collagen locus. However, we observed clinical variations in the severity of the disease in the different families studied, suggesting that the molecular defect within the type VII collagen gene might be different from family to family. Moreover, the absence of linkage disequilibrium between the disease allele and the Pvull RFLP in the families studied suggests an independent emergence of mutant alleles.

Because RDEB consists of different subtypes, it has been speculated that mutations at different loci are responsible for clinical heterogeneity (35). So far, we cannot exclude linkage between another gene and the disease in other affected families. However, our present findings showing linkage between the type VII collagen gene and generalized mutilating RDEB of varying severity, together with the fact that all forms of RDEB so far described also display abnormal and/or reduced anchoring fibrils (2), suggest that different mutations in the same locus could well account for the variability of expression among affected individuals.

Interestingly, the dominant form of dystrophic EB, which also involves major abnormalities of anchoring fibrils (11), has recently been shown to be genetically linked to the type VII collagen gene in three DDEB families $(21,22)$. This form of EB is associated with abnormal and reduced (but not completely absent) anchoring fibrils, and presents positive immunostaining of type VII collagen at the basement membrane zone $(13,15)$. In that DDEB and RDEB exhibit significant clinical, electronmicroscopic, and immunocytochemical differences, it seems likely that the nature of the molecular defect within the type VII collagen gene is different. By analogy with other inherited disorders of connective tissue caused by defects in collagen genes (36), distinct mutations in the gene encoding type VII collagen could well account for dominant or recessive phenotypes, depending on their deleterious effects on synthesis, secretion, folding, or fibril formation. In particular, structurally defective collagen molecules that interfere either with the folding of the triple helix or with self-assembly into fibrils could result in the degradation of the normal molecules which participate in the supramolecular organization of the collagen fibers. This phenomenon referred to as "procollagen suicide," has been previously reported as the molecular basis of dominant inheritance of type I osteogenesis imperfecta (37). Similar mutations within the type VII collagen gene are likely to be associated with the dominant form of dystrophic EB, whereas mutations that prevent expression of type VII collagen, or give rise to a truncated type VII collagen molecule unable to interact with normal type VII collagen in carriers, could be responsible for the recessive forms. Delineation of the molecular defects associated with the DDEB and RDEB phenotypes should en- 
able these hypotheses to be tested, and help to identify the mechanisms underlying impaired anchoring fibril formation in dystrophic EB.

Finally, the characterization of a Pvull RFLP within an exon of the type VII collagen gene, detected by digestion of an amplified product of genomic DNA, will be useful in the development of a rapid method for detection of carriers as well as for accurate prenatal diagnosis in affected informative families.

\section{Acknowledgments}

We are grateful to Mrs. A. Bullot, Mrs. S. Boisson, Dr. A. M. Christiano, Dr. L. C. Chung-Honet, Prof. H. Condamine, Mrs. F. Froissart, Dr. R. Grossman, Mrs. D. Hillaire, Dr. E. Pollack, and to the persons working at the "banque" of Genethon for their expert technical assistance, to the Epidermolyse Bulleuse Association Entraide (EBAE), and to all patients with RDEB and their family members.

This work was supported by grants from the Association Française contre les Myopathies (AFM), the Institut National de la Santé et de la Recherche Médicale (INSERM) and the Centre National pour la Recherche Scientifique (CNRS), and the U.S. Public Health Service (P01-AR38923).

\section{References}

1. Cooper, T. W., and E. A. Bauer. 1984. Epidermolysis bullosa: a review. Ped. Dermatol. 1:181-188.

2. Fine, J. D., E. A. Bauer, R. A. Briggaman, D. M. Carter, R. A. Eady, N. B. Esterly, K. A. Holbrook, S. Hurwitz, L. Johnson, A. Lin, et al. 1991. Revised clinical and laboratory criteria for subtypes of inherited epidermolysis bullosa: a consensus report by the subcommittee on diagnosis and classification of the national epidermolysis bullosa registry. J. Am. Acad. Dermatol. 24:119-135.

3. Bonifas, J. M., A. L. Rothman, and E. H. Epstein, Jr. 1991. Epidermolysis bullosa simplex: evidence in two families for keratin gene abnormalities. Science (Wash. DC). 254:1202-1205.

4. Coulombe, P. A., M. E. Hutton, A. Letai, A. Herbert, A. S. Paller, and E. Fuchs. 1991. Point mutations in human keratin 14 genes of epidermolysis bullosa simplex patients: genetic and functional analyses. Cell. 66:1301-1311.

5. Lane, E. B., E. L. Rugg, H. Navsaria, I. M. Leigh, A. H. M. Heagerty, A Ishida-Yamamoto, and R. A. J. Eady. 1992. A mutation in the conserved helix termination peptide of keratin 5 in hereditary skin blistering. Nature (Lond.). 356:244-246.

6. Gedde-Dahl, T., Jr. 1981. Sixteen types of epidermolysis bullosa. On the clinical discrimination, therapy and prenatal diagnosis. Acta. Dermatol. Venereol. suppl. 95:74-78.

7. Sakai, L. Y., D. R. Keene, N. P. Morris, and R. E. Burgeson. 1986. Type VII collagen is a major structural component of anchoring fibrils. J. Cell Biol. 103:1577-1586.

8. Burgeson, R. E., G. P. Lunstrum, B. Rokosova, C. S. Rimberg, L. M. Rosenbaum, and D. R. Keene. 1990. The structure and function of type VII collagen. Ann. N. Y. Acad. Sci. 580:32-43.

9. Hashimoto, I., U. W. Schnyder, I. Anton-Lamprecht, and T. Gedde-Dahl 1976. Ultrastructural studies in epidermolysis bullosa hereditaria. III: recessive dystrophic types with dermolytic blistering (Hallopeau-Siemens types and inverse type). Arch. Dermatol. Res. 256:137-150.

10. Briggaman, R. A., and C. E. Wheeler. 1985. Epidermolysis bullosa dystrophica recessive: a possible role of anchoring fibrils in the pathogenesis. $J$. Invest. Dermatol. 65:203-211.

11. Tidman, M. J., and R. A. J. Eady. 1985. Evaluation of anchoring fibrils and other components of the dermal-epidermal junction in dystrophic epidermolysis bullosa by a quantitative ultrastructural technique. J. Invest. Dermatol. 84:374-377.

12. Briggaman, R. A. 1985 . Is there any specificity to defects of anchoring fibrils in epidermolysis bullosa dystrophica, and what does this mean in terms of pathogenesis? J. Invest. Dermatol. 84:371-373.

13. Heagerty, A. H. M., A. R. Kennedy, I. M. Leigh, P. Purkis, and R. A. J. Eady. 1986. Identification of an epidermal basement membrane defect in recessive forms of dystrophic epidermolysis bullosa by LH7: 2 monoclonal antibody: use in diagnosis. Br. J. Dermatol. 115:125-131.

14. Leigh, I. M., R. A. J. Eady, A. H. M. Heagerty, P. E. Purkis, and P. A. Whitehead, and R. E. Burgeson. 1988. Type VII collagen is a normal component of epidermal basement membrane, which shows altered expression in recessive dystrophic epidermolysis bullosa. J. Invest. Dermatol. 90:639-642.
15. Bruckner-Tuderman, L., S. Rüegger, B. Odermatt, Y. Mitsuhashi, and U. W. Schnyder. 1988. Lack of type VII collagen in unaffected skin of patients with severe recessive dystrophic epidermolysis bullosa. Dermatologica (Basel). 176:57-64.

16. Bruckner-Tuderman, L., Y. Mitsuhashi, U. W. Schnyder, and P. Bruckner. 1989. Anchoring fibrils and type VII collagen are absent from skin in severe recessive dystrophic epidermolysis bullosa. J. Invest. Dermatol. 93:3-9.

17. Rusenko, K. W., W. R. Gammon, J. D. Fine, and R. A. Briggaman. 1989. The carboxy-terminal domain of type VII collagen is present at the basement membrane in recessive dystrophic epidermolysis bullosa. J. Invest. Dermatol. 92:623-627.

18. Bruckner-Tuderman, L., K. M. Niemi, M. Kero, U. W. Schnyder, and T. Reunala. 1990. Type VII collagen is expressed but anchoring fibrils are defective in dystrophic epidermolysis bullosa inversa. Br. J. Dermatol. 122:383-390.

19. Fine, J.-D., Y. Horiguchi, D. H. Stein, N. B. Esterly, and I. M. Leigh. 1990. Intraepidermal type VII collagen: evidence for abnormal intracytoplasmic processing of a major basement membrane protein in rare patients with dominant and possibly localized recessive forms of dystrophic epidermolysis bullosa. J. Am. Acad. Dermatol. 22:188-195.

20. Smith, L. T., and V. P. Sybert. 1990. Intra-epidermal retention of type VII collagen in a patient with recessive dystrophic epidermolysis bullosa. J. Invest. Dermatol. 94:261-264.

21. Ryynänen, M., R. G. Knowlton, M. G. Parente, L. C. Chung, M.-L. Chu, and J. Uitto. 1991. Human type VII collagen: genetic linkage of the gene (COL7A1) on chromosome 3 to dominant dystrophic epidermolysis bullosa. Am. J. Hum. Genet. 49:797-803.

22. Ryynänen, M., J. Ryynänen, S. Sollberg, R. V. Iozzo, R. G. Knowlton, and J. Uitto. 1992. Genetic linkage of type VII collagen (COL7A1) to dominant dystrophic epidermolysis bullosa in families with abnormal anchoring fibrils. $J$. Clin. Invest. 89:974-980.

23. Parente, M. G., L. C. Chung, J. Ryynänen, D. T. Woodley, K. C. Wynn, E. A. Bauer, M-G. Mattei, M-L. Chu, and J. Uitto. 1991. Human type VII collagen: cDNA cloning and chromosomal mapping of the gene. Proc. Natl. Acad. Sci. USA. 88:6931-6935.

24. Anton-Lamprecht, I., V. Jovanovic, M-L. Arnold, R. Rauskolb, and W. Schenck. 1981. Prenatal diagnosis of genetic disorders of the skin by means of electron microscopy. Hum. Genet. 59:392-405.

25. Saiki, R. K., D. H. Gelfand, S. Stoffel, S. J. Scharf, R. Higuchi, G. T. Horn, K. B. Mullis, and H. A. Erlich. 1988. Primer-directed enzymatic amplification of DNA with a thermostable DNA polymerase. Science (Wash. DC). 239:487-491.

26. Gyllensten, U. B., and H. A. Erlich. 1988. Generation of single-strand DNA by the polymerase chain reaction and its application to direct sequencing of the HLA-DQA locus. Proc. Natl. Acad. Sci. USA. 85:7652-7656.

27. Sanger, F., S. Nicklen, and A. R. Coulson. 1977. DNA sequencing with chain-terminating inhibitors. Proc. Natl. Acad. Sci. USA. 74:5463-5467.

28. Lathrop, M. G., and J. M. Lalouel. 1984. Easy calculations of lod scores and genetic risks on small computers. Am. J. Hum. Genet. 36:460-465.

29. Ott, J. 1985. Analysis of Human Genetic Linkage. The Johns Hopkins University Press, Baltimore, MD. 233 pp.

30. Bauer, E. A. 1986. Collagenase in recessive dystrophic epidermolysis bullosa. Ann. N. Y. Acad. Sci. 460:311-320.

31. Winberg, J-O., T. Gedde-Dahl, and E. A. Bauer. 1989. Collagenase expression in skin fibroblasts from families with recessive dystrophic epidermolysis bullosa. J. Invest. Dermatol. 92:82-85.

32. Sawamura, D., T. Sugawara, I. Hashimoto, L. Bruckner-Tuderman, D. Fujimoto, Y. Okada, N. Utsumi, and H. Shikata. 1991. Increased gene expression of matrix metalloproteinase-3 (stromelysin) in skin fibroblasts from patients with severe recessive dystrophic epidermolysis bullosa. Biochem. Biophys. Res. Commun. 174:1003-1008.

33. Colombi, M., R. Gardella, L. Moro, N. Zoppi, and S. Barlati. 1991. Severe generalized epidermolysis bullosa dystrophica recessive: exclusion of stromelysin-1, interstitial collagenase, fibronectin and urokinase as the mutant loci. In Proceedings of the Annual Meeting of the European Society for Human Genetics, Leuven, Belgium, 13-16 July 1991. 95a. (Abstr.)

34. Hovnanian, A., P. Duquesnoy, S. Amselem, C. Blanchet-Bardon, M. Lathrop, L. Dubertret, and M. Goossens. 1991. Exclusion of linkage between the collagenase gene and generalized recessive dystrophic epidermolysis bullosa phenotype. J. Clin. Invest. 88:1716-1721.

J5. Gedde-Dahl, T. 1986. Clinical heterogeneity in epidermolysis bullosa: seculations on causation and consequence for research. $J$. Invest. Dermatol. 86:91-92.

36. Kuivaniemi, H., G. Tromp, and D. J. Prockop. 1991. Mutations in collagen genes: causes of rare and some common diseases in humans. FASEB (Fed. Am. Soc. Exp. Biol.) J. 5:2052-2060.

37. Prockop, D. J., C. T. Baldwin, and C. D. Constantinou. 1990. Mutations in type I procollagen genes that cause osteogenesis imperfecta. Adv. Hum. Genet. 19:105-132. 